\title{
Species identification using ZooMS, with reference to the exploitation of animal resources in the medieval town of Odense
}

\author{
Luise Ørsted Brandt ${ }^{a}$, Kirstine Haase ${ }^{\mathrm{a}, \mathrm{b}}$ and Matthew J. Collins $\mathbb{1}^{\mathrm{c}, \mathrm{d}}$ \\ ${ }^{a}$ Centre for Urban Network Evolutions, Aarhus University, Aarhus, Denmark; 'bepartment of Cultural Heritage, Odense City Museums, \\ Odense, Denmark; ' ${ }^{2}$ voGenomics, Natural History Museum of Denmark, University of Copenhagen, Copenhagen, Denmark; ${ }^{\mathrm{d} B i o A r C h}$, \\ Department of Archaeology, University of York, York, UK
}

\begin{abstract}
ZooMS (Zooarchaeology by Mass Spectrometry) is increasingly being used as a method for species identification of archaeological and historical remains. The method identifies species from the peptide mass fingerprint of extracted collagen - the principal protein of bone, ivory, dentine, leather, and parchment. ZooMS has the advantages that it is a fast and simple method, that requires only small sample sizes or even non-destructive sampling. The taxonomic resolution of the method varies, but ZooMS is diagnostic for most domesticated animals and for the relatively depauperate Scandinavian fauna, although some groups (seals, martens) cannot be resolved, and it cannot discriminate some domesticates (dog, cattle) from their wild counterparts. In this article, we overview the method and demonstrate the value of ZooMS and illustrate our points via a case study of 20 samples from 12th to 14th century layers in the Danish medieval town of Odense. Four artefacts were tested by a non-destructive eraser technique because of their uniqueness, but only one could be identified. The remaining 16 were identified following destructive analysis of the sample, one sample could not be identified.

Through the identification of a gaming piece as walrus tusk the analysis demonstrated the long distance trade networks of Odense and the pursuit of some inhabitants for luxury products and high living standards. Conversely, the species identification of combs showed that the medieval comb maker would use the resources immediately available to him to create an affordable everyday object rather than rely on imported antler.
\end{abstract}

\section{ARTICLE HISTORY}

Received 30 January 2018

Accepted 19 April 2018

\section{KEYWORDS}

ZooMS; species

identification; collagen;

middle age; animal

resources; long distance

trade; zooarchaeology;

archaeology

\section{Introduction}

The study of animal remains such as bones, skin, and fur in an archaeological context provides insights into past relationships between animals, people, and the environment. Because of the mutual nature of these relationships, animal remains in context have been used to address a wide range of aspects of the human past as amongst many others diet, resource exploitation, animal domestication, economy, environment, trade networks, and cultural identity, and the study is relevant across prehistoric and historic periods, settlement types, and geographical regions (Steele 2015). Identifying the species of animal remains is one of the key prerequisites for discussing such aspects of human culture.

This article explores the protein fingerprinting methodology of ZooMS (Zooarchaeology by Mass Spectrometry, Buckley et al. 2009) which uses amino acid sequence variation in the dominant structural protein, type I collagen, which is abundant in bone, skin, and tissue, for species identification in Scandinavian archaeology. Since its introduction, the method has reached maturity and is becoming increasingly popular within archaeology as it is a cheap, easily applicable, and minimally or even non-destructive method for species identification (Fiddyment et al. 2015, Coutu et al. 2016). Moreover it has been demonstrated to be an excellent method for screening large bone assemblages for specific species (Welker et al. 2016).

In this article, we will introduce ZooMS and then present a case study in which the method has been used as part of an analysis of the 12th to 14th century animal resources from the Danish town of Odense. 


\section{The Scandinavian record}

In many sites in Scandinavia, animal bones and skin (rich in collagen) are common finds whereas fur and woollen textiles (rich in keratin) are rare. In fact, animal bones (with waterlogged wood) are the most abundant organic materials that we come across in urban excavations. They are often present in more or less every cultural layer and deposited in every conceivable way; from intact buried animals to fragments in the form of dietary remains, waste from butchering, worked bone or antler, semi-manufactured artefacts and debris from production, finished, discarded or lost artefacts, or reused animal bones in structures as fills.

Because of its abundance and witness of multiple processes, bone holds great interpretive potential, but it is also one of the most challenging to handle. This is not only due to the complicated processes related to its use and deposition but also because of the circumstances that applies to most excavations in Denmark. The majority of the archaeological excavations in Denmark are rescue excavations that are conducted within the framework of the Danish Museum Act part 8. ${ }^{1}$ This entails economic restrictions and specific guidelines with regards to the analysis of zooarchaeological material. ${ }^{2}$ In practice this implies that it is impossible to collect the preserved bone material in its entirety. The analyses that are carried out are mainly quantitative in nature, where the number of bones, species and sex identification, and their distribution over time are accounted for.

One could argue that collecting all animal bones from a site would be a senseless endeavour, since the excavated material already only represents a part of the original bone assemblage due to selection processes in the past and the following taphonomic processes (Orton 2012). An analysis of the zooarchaeological material from any archaeological site will always have to consider sample bias and fragmented material. This makes it even more important to consider all available information from the archaeological record. Only then it is possible to answer questions such as: What animals provided the raw materials for both food and manufacture of artefacts? Were they local or not? Were some animals preferred over others? And for what purpose? These questions are especially pertinent to the medieval town, since the use of animal resources are part of the economy that sustained life in the town and therefore part of what characterises life in town. Describing these practices on best possible ground will enable us to understand the dynamics that constituted life in the town and ultimately what makes town life different from other forms of existence (Christophersen 2015). In order to answer any of these questions, it is necessary to identify the species of the zooarchaeological material including the material that is not identifiable through morphological characteristics. ZooMS offers to do so in a way that is affordable, reliable, and within the scope of the Danish Museum Act.

\section{Species identification of animal remains}

Species identification of animal bones has traditionally been performed by osteological examinations of the size, morphological characteristics, and surface features of bones that vary between species (O'Connor 2000). This can lead to the determination of the species of its origin by comparing the observed characteristics with characteristics on bones of known species origin from reference collections or animal bone atlases. These morphological species identification methods are especially valuable in that they often provide additional information to the species, such as the bone element, sex and age of the animal, pathology, traces of wear, and the preservation state of the object (Steele 2015). However, the success of osteological species identification depends on the preservation of the diagnostic characteristics of bones and the opportunity to identify them. Diagnostic characteristics may be lost due to, for instance, processing bones for consumption, working bone into artefacts, taphonomic processes such as weathering and gnawing or diagenetic processes following burial (Lee Lyman 1994). If some animal bones are more heavily processed than others, their importance may be overlooked as their fragments may be less recognisable. Even for well-preserved bones, both wild and domesticated species may display significant variations of bone elements within a species for instance between males and females and between different populations (Hillson 1992). This means that considerable expertise is required for reliable identifications, but also access to reference collections encompassing all such interspecies 
variations. The last is further a challenge as some species are known to have changed morphologically over the past millennia and during domestication. Examples of this is a great diversity of horns in cattle, sheep, and goat after domestication and a shortening of the face region and jaws seen in for instance domesticated dogs and pigs (CluttonBrock 1999).

When diagnostic features are not preserved, archaeologists are left with no species identification or identification to a higher taxonomic level, which can lead to large percentages of unidentified bones and bias the interpretations of a bone assemblage (Badenhorst and Plug 2011); indeed archaeologists include the term ovicaprid due to the difficulty of discriminating sheep from goat.

Over the past two decades, developments within biomolecular archaeology have resulted in a range of technologies which are applicable for species identification of archaeological material. Of these, the analysis of ancient DNA is probably the most well-known. DNA from a range of archaeological materials has been successfully extracted and sequenced both targeting short fragments of mitochondrial DNA using PCR (Polymerase Chain Reaction) and larger parts of the genome using Next Generation Sequencing (NGS) technologies. Such studies have provided species identifications of animal bone, skin, and hair (Fiddyment et al. 2015, Brown et al. 2016, O'Sullivan et al. 2016, Welker 2017). The great advantage of DNA studies is the high resolution which allows the distinction between even closely related animal species, and male from female, but also it can discriminate populations, and identify migrations (Cassidy et al. 2017, Librado et al. 2017). NGS analyses are still relatively expensive and time consuming and the success of aDNA analysis largely depends upon the preservation of DNA, a process which is still poorly understood (Smith et al. 2003, Kistler et al. 2017). However, materials with no preserved DNA may not be out of reach for species identification.

Over the past years, proteins have been demonstrated to persist for longer than DNA and can be recovered in environments from which DNA cannot be amplified (e.g. eggshell, Demarchi et al. 2016, and bone, Welker et al. 2015a, Westbury et al. 2017). In the case of skin capes from Danish bogs dating to the Iron Age (Schmidt et al. 2013), DNA identification failed, whereas a proteomic approach was able to provide species identifications of the skins. More than this, proteins can be tissue and developmentally specific, and the study above provided additional information on the use of young (calf) skin for one of the capes (Brandt et al. 2014). Both NGS-based DNA approaches and proteomics methods are however relatively expensive and time consuming. In many cases, merely species identification can be the most relevant information for answering an archaeological question together with traditional zooarchaeological analysis such as quantification, animal size, element processing, etc.

\section{ZooMS - Zooarchaeology by Mass Spectrometry}

Whereas shotgun proteomics, as the name suggests, targets all proteins preserved in a sample, ZooMS usually targets the protein collagen, the most abundant protein in animals where it is found in connective tissues, bone, antler, teeth, and skin (Shoulders and Raines 2009). So far, 28 collagen types are described. Of these, type I collagen is the most abundant and found in various tissues including bone, skin, ligament, and tendon. It is a tough, insoluble protein, which is difficult to biodegrade if protected by mineral (bone, dentine, antler) or tanned (leather). Consequently it is the most common protein recovered from archaeological environments. In higher vertebrates, type I collagen consists of three polypeptide chains: two collagen a 1 chains and one collagen $a 2$ chain, which are coiled into an extended proline triple helix. Collagen forms a nanorope; the triple helices self assemble into larger collagen microfibrils, which aggregate to form collagen fibres (Shoulders and Raines 2009).

After collagen, the second most widely studied protein from archaeological remains is keratin, found in instance wool, hair, nail, hoof, beak, and feathers (Hollemeyer et al. 2002, 2007, 2008, 2012, Solazzo et al. 2013, 2014, Solazzo 2017).

\section{Sampling}

When analysing archaeological material only small samples are needed. For example, 'empty' tubes used to process collagen for radiocarbon dating (Charlton et al. 2016) and eraser rubbings used to clean parchment (Fiddyment et al. 2015), have both been used. In the case of archaeological samples, $10-30 \mathrm{mg}$ of 


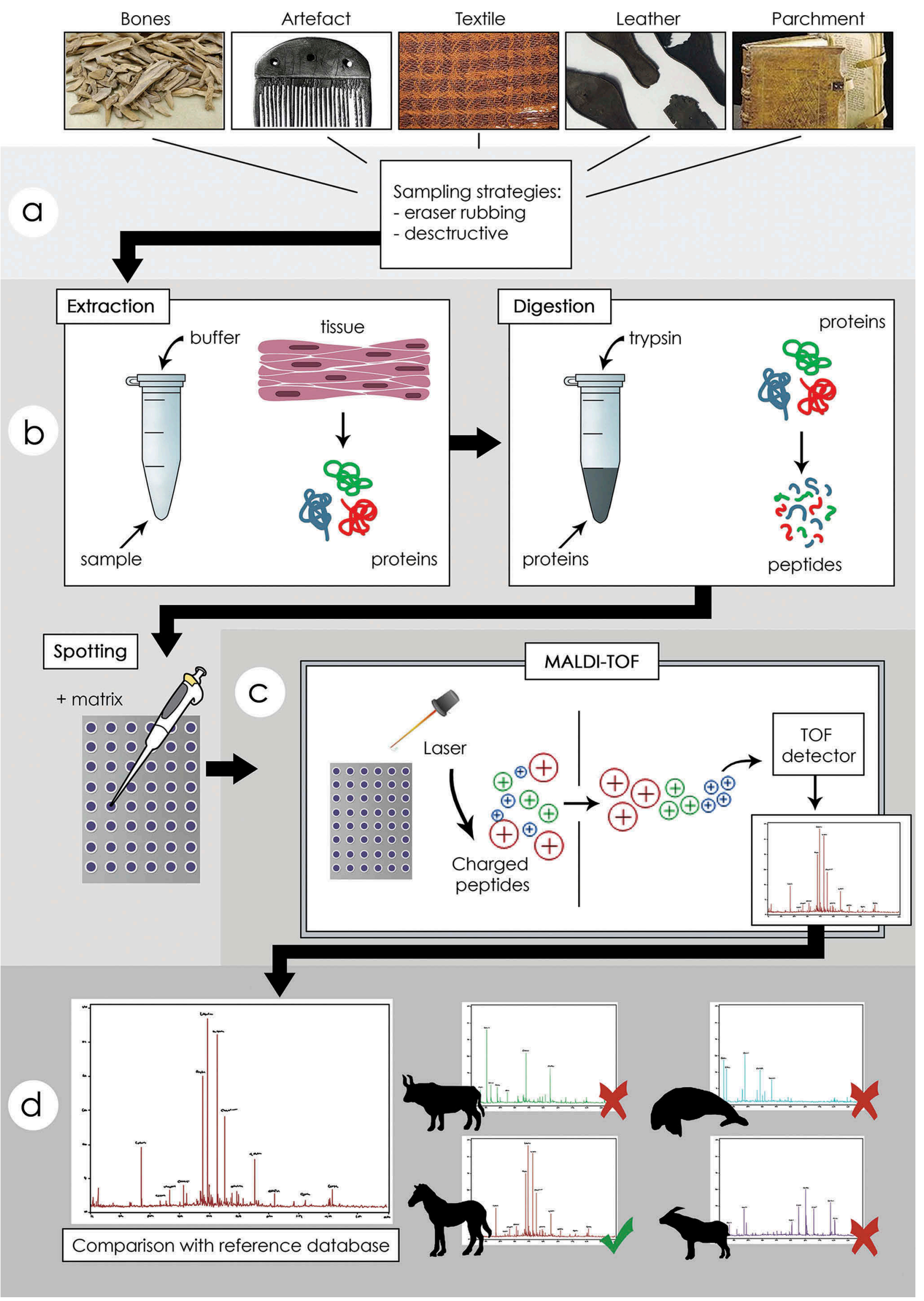

Figure 1. Flow chart of the ZooMS process. Graphics: Sidsel Frisch. 
bone (depending on whether bone chips or bone powder is used) or pinhead of skin is sufficient (Figure 1(a)). Being able to sample non-destructively is crucial for getting access to materials from which a sample cannot be spared.

\section{Extraction and digestion of collagen}

The extraction protocol varies according to material and strategy (Figure 1(b)). For bone samples, a destructive demineralisation can be applied to dissolve the bones mineral component using hydrochloric acid, which leaves a collagen pellet that can be gelatinised using ammonium bicarbonate (Buckley et al. 2009). An alternative and non-destructive approach has been developed (Van Doorn et al. 2011), which avoids the demineralisation step, extracts sufficient collagen for ZooMS, and leaves the sample undamaged.

Regardless of the extraction method, the subsequent digestion is usually the same. The solubilised collagen (gelatin) is cleaved using the enzyme trypsin into shorter chains of amino acids (peptides) at lysine and arginine residues. Together lysine and arginine represent about $10 \%$ of all the residues in collagen, but they are not evenly distributed over collagen, thus although the average length of a chain will be about 10 residues, resulting peptides will have a varying length, composition, and mass. It is these masses, when known to vary between animal species, due to differences in the amino acid sequence, which enable species identification. However, the low degree of sequence variation in collagen, and the degree of structural constraint means that different peptides can share the same mass. The peptide digests are desalted, typically using C18 columns (ZipTips) and eluted in (TFA) acidified acetonitrile. It is possible to fractionate the eluent from the ZipTip by using different concentrations of solvent. $1 \mathrm{ul}$ of each sample is spotted in triplicate onto a plate (both disposable plastic and reusable stainless steel can be used) to which $1 \mathrm{ul}$ of matrix is added, and the two co-crystallise.

\section{Analysis}

The mass of each peptide is measured using MatrixAssisted Laser Desorption/Ionization Time of Flight Mass Spectrometry (MALDI-TOF) (Figure 1(c)). A laser is targeted at matrix crystals formed as the sample dries on the plate. Using a compatible wavelength to the matrix, the absorbed energy causes the (acidic) crystals to volatilise transferring charge (a single proton) to some of the co-crystallised peptides. An electric field accelerates the volatile charged peptides down a vacuum tube, towards and ion mirror which doubles the length of the flight path and helps focus the ions towards the detector. As all peptides carry a single charge, the smaller and lighter peptides travel faster down the tube than the larger and heavier ones. The time of flight to reach the detector can be used to estimate the mass of the peptide and the resulting peaks generated on a spectrum reflects the mass and the intensity of the detected collagen peptides. Each sample therefore gives a fingerprint of masses of the constituent collagen peptides.

\section{Identification}

It is typical to run triplicate spectra, as differences in co-crystallisation impact upon system performance. The three spectra resulting from the triplicate spots of each sample can be averaged and analysed using software tools such as mMass (Strohalm et al. 2008).

Masses which represent collagen peptides of different masses are recognised. The masses are then compared to a list of collagen peptide masses from the species that have been analysed, or predicted from sequences. By comparing the masses, it will be possible to rule out species (Figure 1(d)). The more peaks recognised on the spectra, the better the chance for a specific identification. In the ideal situation, the peaks will represent masses that are diagnostic for only one species. Some species are however so closely related that it will not be possible to distinguish them (Buckley et al. 2011, Coutu et al. 2016). Mammals have been the primary focus for ZooMS identifications, but the reference database also includes markers for fish (Richter et al. 2011) and markers for eggshell from birds (Stewart et al. 2013, Presslee et al. 2018) and is constantly expanding.

Depending on the extraction method, the entire analysis from sampling to analysis can be carried out in few days. Altogether ZooMS therefore represents a minimally or even non-destructive, cheap, easily applicable, and fast method for species 
identification of archaeological remains rich on collagen or keratin.

\section{Case study: animal remains from medieval Odense}

\section{The site}

From May 2013 to September 2014 a large rescue excavation prior to construction work took place in Odense; the third largest town in present day Denmark.

Odense is first mentioned in a letter in $988 .{ }^{3}$ Also, in the 10th century, a Viking ring fortress was built in Odense, in the 1040s it is possible that minting took place, and in 1086 King Canute (the Holy) was killed before the altar in St. Albany Church and later canonised (Christensen 1988). These events all suggest that Odense was a significant settlement already in the 11th century although it has been difficult to characterise the settlement further through the archaeological record. ${ }^{4}$ By the 13th century, Odense acquired market rights and the archaeological and written records testifies to a vibrant and growing town that maintains its position as one of the most important towns in Denmark throughout the Middle Ages.

An area of $2500 \mathrm{~m}^{2}$ with approximately $4300 \mathrm{~m}^{3}$ of cultural layers in the central part of the medieval town
Table 1. Number of animal bone fragments from the 2013-2014 excavation in Odense (OBM9776) and their distribution through time.

\begin{tabular}{lc}
\hline Period & No. of fragments \\
\hline-1100 & 848 \\
12th Century & 12.031 \\
13th Century & 30.404 \\
14th Century & 31.956 \\
15th Century & 8.843 \\
After 1500 & 100 \\
In total & 84.182 \\
\hline
\end{tabular}

was excavated. A coherent area of that size and location had prior to this never been excavated in Odense. All though the area had been heavily truncated by modern construction activity the preservation conditions for wood, bone, and other organic material were surprisingly excellent. Both an extensive finds assemblage and well-preserved structures such as stalls, houses, stables, latrines, paths, roads, fences, manure heaps, and much more was brought to light. This presented a unique opportunity to study the period from the 11th to 16th century CE in Odense in detail (Figure 2).

\section{Zooarchaeological results}

A total of 84,182 fragments of animal bones were recovered from the cultural layers - all as the result of an extensive sieving procedure (Table 1). Of these it was possible to identify the species or family level of 40,913 fragments which illustrates the challenges in

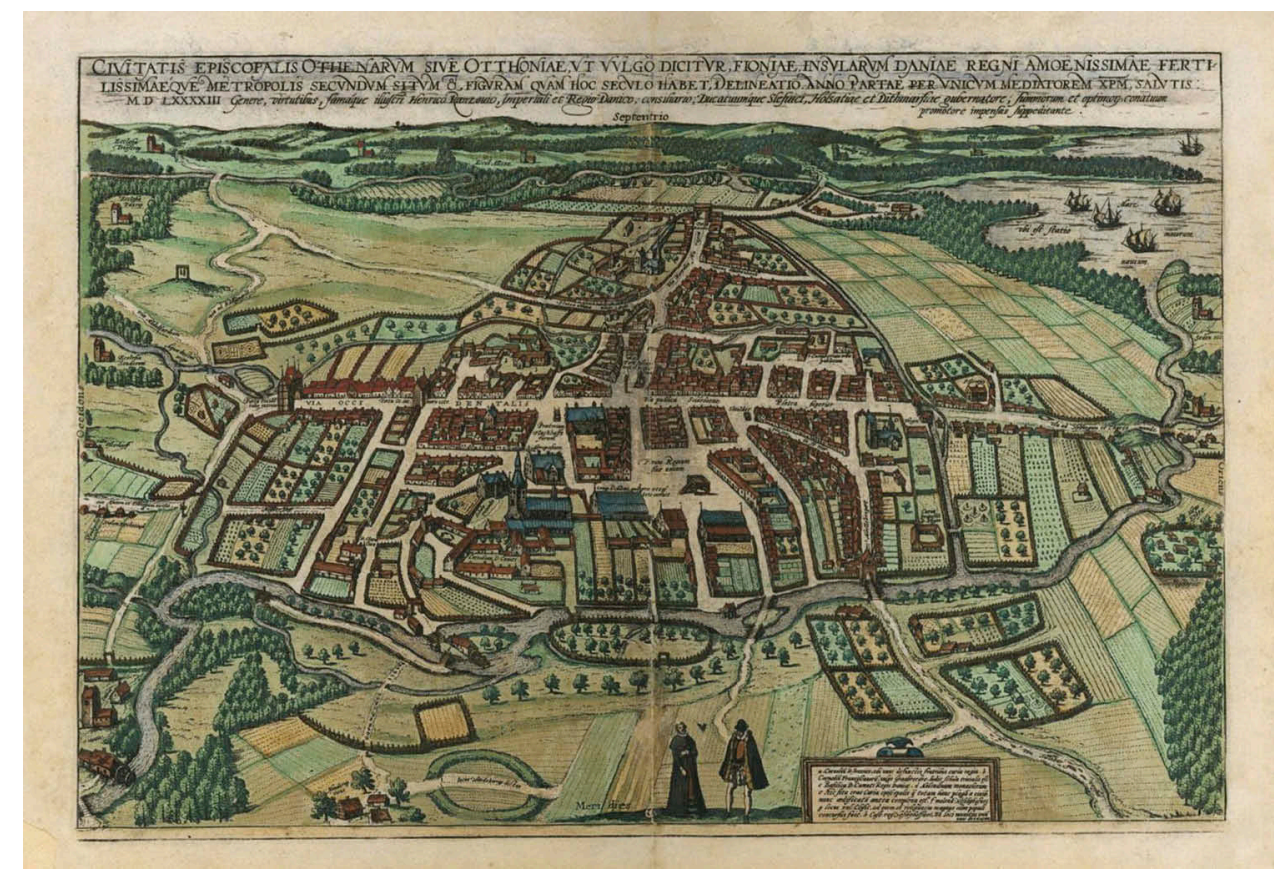

Figure 2. Odense around 1593 AD - Braun \& Hogenberg Civitates orbis terrarum Vol. V. 

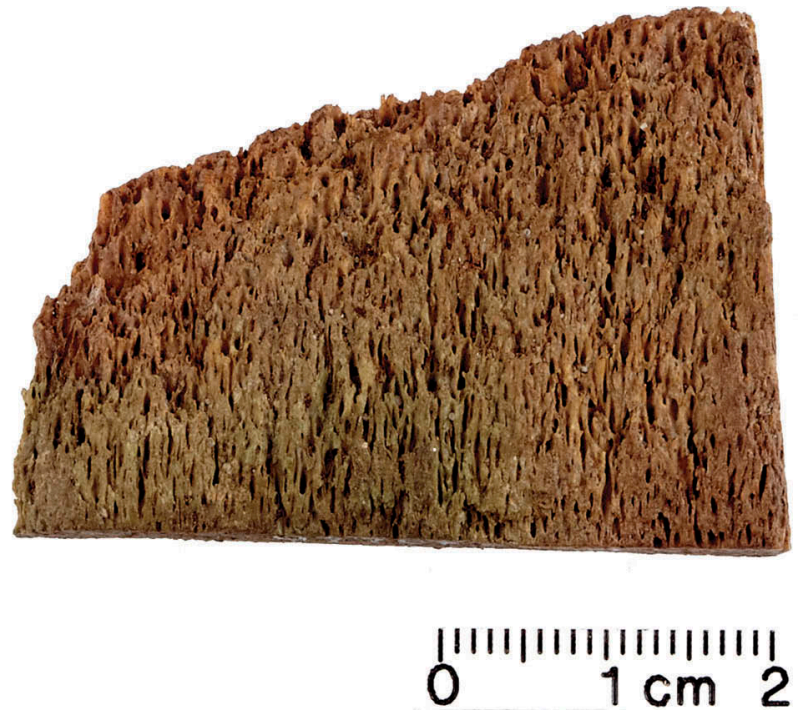

Figure 3. Photo of a piece of worked right whale bone (x5850). Photo: Nermin Hasic, Odense City Museums.

working with this often fragmented material. In spite of only half of the bones being identified, the results of the excavations and the zooarchaeological analysis demonstrate that a wide range of domestic animals such as horse, pig, cattle, sheep, and goat have been an important contribution to life in town from the 11th to 16th centuries (Østergaard 2016). On each stage of their life-history, these animals would be an almost indispensable resource acting as draught animals, providing milk, meat, and raw materials such as leather and bone for manufacturing various objects.

A total of 208 artefacts were produced of either antler or animal bone. Amongst these were semi-manufacture, production waste, needles, dice, combs, mounts, gaming pieces, handles, and a number of artefacts that could not be identified apart from the material; bone or antler. Forty of the 208 artefacts were identified to species level through morphological traits - most of these to red deer antler. 26 artefacts were identified as either a large or a small mammal. Amongst the artefacts for which the raw material could not be identified, 20 were selected for further analysis. These artefacts were chosen because they had a solid relation to an archaeological context and because this context was well-defined both stratigraphically and with regards to their interpretation. In addition, some were selected because of their unusual appearance (e.g. Figure 3). Finally, 13 samples were included because they were interpreted as being either combs, parts of combs, semi-manufacture, or production waste from comb-production. The artefacts were moreover chosen so they spread over the 12th, 13th, and 14th century as one of the research questions was whether the selection of raw material for combs had changed over time. Another question was whether antler used for comb production derived from local animals from medieval Denmark, or from imported raw materials (Roesdahl 1999, Linaa 2015). A recent study of comb making in Viking Age Ribe, Århus and Aggersborg (Denmark) successfully used ZooMS to identify the raw material used as mainly cervid (red deer, roe deer, and reindeer, Ashby et al. 2015, 679-704). Also, Von Holstein et al. (2014) used ZooMS and DNA to explore evidence of trade with Scandinavia in pre-Viking Scottish combs. The number of samples from Odense was too small to give a representative picture of the development and the characteristics of use of animal resources and the analysis served therefore as a pilot project.

\section{ZooMS analysis}

For 16 of 20 bone samples, ZooMS was carried out using demineralisation according to Buckley et al. (2009) and for four samples using the non-destructive sampling with eraser (Fiddyment et al. 2015). Non-invasive sampling removes collagen using the triboelectric effect and was chosen, because it avoids the need to take a physical sample, when sampling complete or unique artefacts.

Table 2. Results of ZooMS identifications on 20 samples from the 2013-2014 excavation in Odense (OBM9776).

\begin{tabular}{lll}
\hline & \multicolumn{1}{c}{ Sampling technique } & \\
\cline { 1 - 2 } Specimen no. & $\begin{array}{c}\text { Destructive (Buckley et al. } \\
\text { 2009), Non-destructive } \\
\text { (Fiddyment et al. 2015) }\end{array}$ & \multicolumn{1}{c}{ Species ID } \\
\hline x1276 & Destructive & Cattle \\
x3025 & Destructive & Bovid/cervid \\
x3116 & Non-destructive & No ID \\
x3595 & Non-destructive & No ID \\
x4685 & Destructive & Bovid/cervid \\
x4715 & Destructive & Bovid/cervid \\
x4974 & Non-destructive & Bovid/cervid \\
x5559 & Destructive & Cattle \\
x5651 & Destructive & No ID \\
x5794 & Non-destructive & No ID \\
x5850 & Destructive & Right whale \\
x5864 & Destructive & Cattle \\
x5875 & Destructive & Red deer/fallow deer \\
x5953 & Destructive & No ID \\
x6732 & Destructive & Sperm whale \\
x7341 & Destructive & Atlantic walrus \\
x7378 & Destructive & Pig \\
x7564 & Destructive & Horse \\
x7576 & Destructive & Horse \\
x852 & Destructive & Bovid/cervid \\
\hline
\end{tabular}




\section{Results}

Identification to species was possible for nine of 20 samples. Five samples failed to yield any identifications, while five samples were identified to the level of bovid ${ }^{5}$ or cervid ${ }^{6}$ and one to red deer or fallow deer (Table 2).

The possibility of identifying a sample depends first of all on the presence of collagen in the sample. It moreover requires that there are known differences between species and that peptides with these diagnostic masses are preserved. Not all the diagnostic peptides are identified in every sample and therefore identification will often be limited to a higher taxonomic level. To illustrate this, we have chosen the example of the whale, for which the 1682 peak is not shared with any other species. This provides a unique identification of the artefact to right whale (Buckley et al. 2014) (Figure 3).
Another example is the identification to a larger group of bovids and cervids present in the database. For OBM9776 $\mathrm{x} 852$, the presence of the peak $1427 \mathrm{~m} / \mathrm{z}$ is shared between Bovidae such as sheep, goat, cattle, and gazelle and Cervidae such as reindeer, roe deer, fallow deer, red deer. ${ }^{7}$ Therefore, if there are no other peaks present on the spectra that differ between these species, the identification will be bovid/cervid. However, the peptide with the weight of 1427 differs from the peptide found in for instance pig, dog, and marine mammals, which after all excludes a range of species. If no diagnostic peaks are present, the result will be No ID.

\section{The combs}

The results of the pilot ZooMS analysis were somewhat surprising. As expected the medieval combs were primarily from animal bone. Generally it is widely accepted that medieval combs or combs manufactured in the 13th century and later are made from bone rather than antler

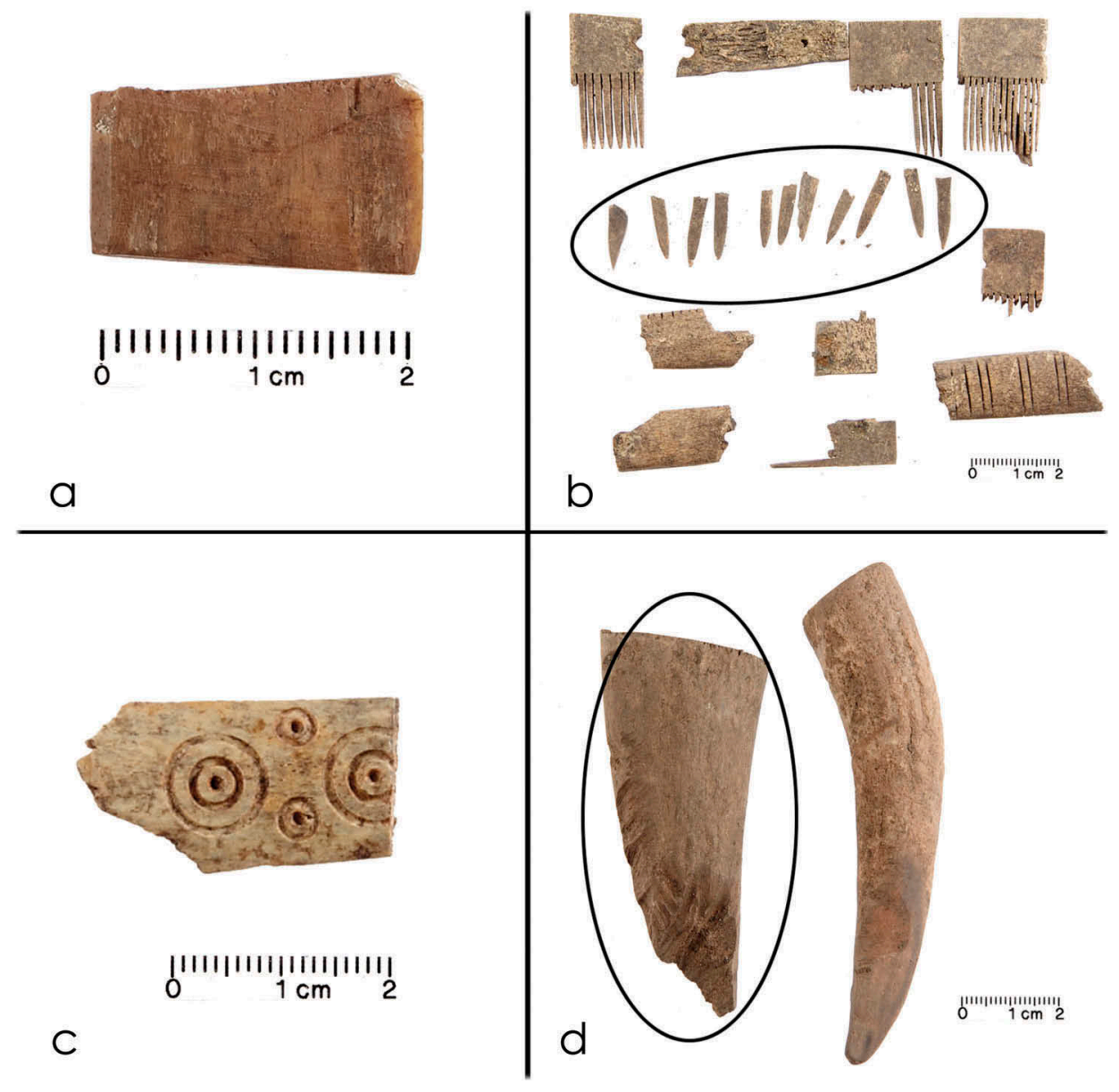

Figure 4. A selection of the analysed items. A: Horse (x7564), B: Pig (x7378), C: Bovid/Cervid (x4715), and D: Red deer/Fallow deer (x5875). Photo: Nermin Hasic, Odense City Museums. 
(Øye 2005, Ashby 2009). The surprise was rather the diversity in the choice of species used for comb manufacture (Figure 4). For those parts with a positive identification, beyond bovid/cervid, the ZooMS analyses showed that cattle was the primary source for connecting plates $(\mathrm{x} 5559, \mathrm{x} 1276)$ whereas horse, pig, cattle, and even bone from sperm whale have been used for making tooth plates (x7378, x7564, x5864, x6732). There was no positive identification for reindeer, roe deer, fallow deer, or red deer in any of the artefacts that with certainty could be related to comb production.

The presence of sperm whale (identified by key marker 2133 (Buckley et al. 2014)) was unexpected. Sperm whales are rare guests in the waters around Funen, but in the present day there are regular beachings of sperm whales on the west coast of Jutland, which might also have been the case in the Middle Ages. The beached whale belonged to the king, but locals were allowed some parts of it (Hybel and Poulsen 2007, 55). Maybe this was how the sperm whale bone ended up in Odense, brought there by a visitor or a merchant from Jutland. It does not seem that the comb maker distinguished between raw material from either small (pig) or large (horse, whale) animals. Horse bone was a very rare find amongst the animal bones $(0,1 \%)$ in Odense and the main part of that material was represented by a complete horse that had been buried in a landfill area sometime during the 14th century (Østergaard 2016). The bones of this horse had cut marks which suggest that it had been skinned. Horses were mainly used for riding or as draught animals in the medieval period, but their skin would be used for leather. Finds of production waste from horse bone in Århus and Ribe suggest that it was not unusual to use horse bone in comb making in the Viking and medieval period (Møhl 1971, Enghoff 2006). ${ }^{8}$ In the aforementioned study from 2015, horse was found in a finished comb from Århus (Ashby et al. 2015, 690). In spite of the complicated procedure with removal of the flesh, etc. the examples show that horse bone may have played a larger role as raw material than the bone assemblage from Odense alone suggested.

With some precaution in regards to the small number of samples we may conclude that the medieval combs are a product of the town to a much larger degree than the Viking Age comb (Larsen 2005, Frandsen 2006, Ashby et al. 2015). It was possible to procure the raw material within the town limits including animals that would probably not be used for dietary purposes - the horse. Antler was still used in comb production, as contemporary antler production waste from the area indicate, but it is most likely only from local red or fallow deer. The analysis suggests that at least half of the objects with relation to comb production were made from different types of animal bone (horse, whale, pig, and cattle) and not antler. This was either because of difficulties in access to antler or a desire to use the raw material available within the town perimeter. A cost-effective method that would make the comb a very affordable product and probably also enable a mass production since the raw material was present in abundance. Instead of being dependant on raw material from outside the town the comb maker would operate within the town limits. Even the copper used for the rivets, that would attach the connecting plates to the tooth plates, may have been made from reused material.

These considerations also leads to the suggestion that using a specific type of antler in Viking Age combs was a very conscious and active choice since the Viking Age comb makers also would have had access to animal bones as raw material. It does not seem to have any functional or visual consequence whether animal bone or antler is used as raw material for the comb. Instead there might be some underlying symbolic meaning in the Viking Age comb makers choice of material (Ashby 2014, 99-121). The change of raw material indicates that the comb changes from being an exclusive product to a more accessible and affordable everyday product (Figure 5).

\section{The exotica}

A couple of exotic species turned up amongst the species identifications by ZooMS. One was the Atlantic walrus (Figure 6) and the other was a right whale. The piece identified as walrus was a part of walrus tusk also known as 'the ivory of the north' in the Middle Ages. Walrus tusk was used as gaming pieces, mounts or decorations for caskets or other decorative items. They were highly prestigious items and a luxury good. The piece from Odense may be part of a gaming piece, but it has not been possible to give a positive identification. It was found in the activity layers that had accumulated around a 14th century market stall. It is possible that it was part of what was sold from the stall but it is also possible that it was lost accidentally in the busy crowd by one of the customers. 


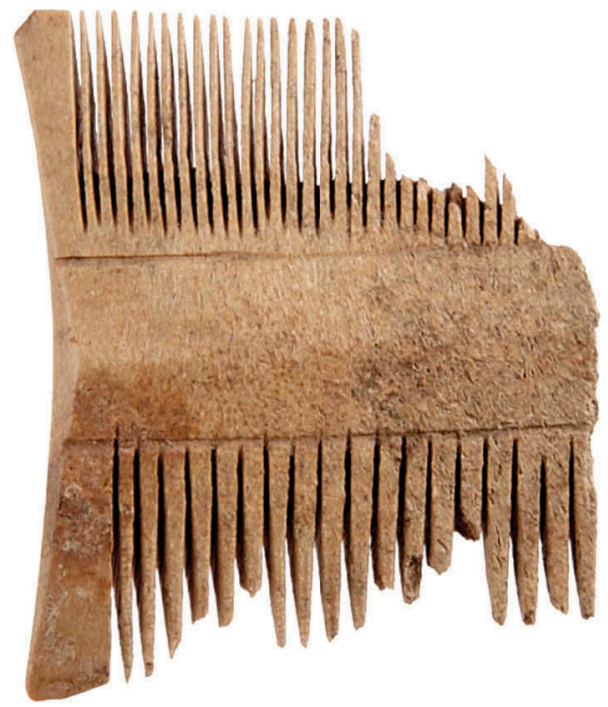

0

Figure 5. A small one-piece double-sided comb made from bovid/cervid bone (x3025). Photo: Nermin Hasic, Odense City Museums.

The Atlantic walrus was traded all over Europe from Iceland and Greenland as early as the 13th century as mentioned in Kongespejlet (Latin: Speculum regale c. 1220-30 AD) (Brøgger 1947). They were hunted by the Norse who settled on the south-west coast of Greenland from around 1000 to the early 14th century (Jensen and Østergaard 2017, 178). In 1327 the Greenlandic tithes were paid through sale of walrus tusk (Liebgott 1985, 10-11; Jette Arneborg 2000, 304-305). Findings of walrus skulls in Norse farms show that it was mainly the tusks - and probably also the hide - that was the most desired part of the walrus (Arneborg 1999). Walrus found in Denmark may have been traded through Norway.

The presence of walrus tusk in Odense both evidences the trade connections of the town and also a rise in living standards paralleling trends elsewhere in Europe.

\section{Discussion}

The ZooMS analysis of bone artefacts from medieval Odense demonstrates the potential of ZooMS for species identification a group of materials that have until now remained silent: artefacts without recognisable morphological traits. Until now such

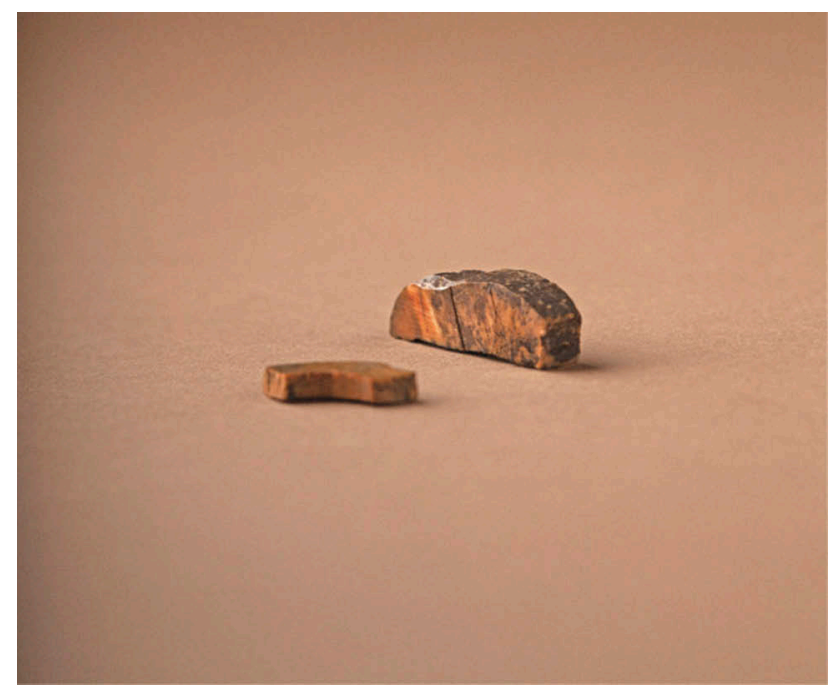

Figure 6. Two small pieces of worked walrus tusk which might have served as gaming pieces. OBM $9776 \times 731$. Photo: Peter Helles Eriksen.

artefacts have mainly been treated in relation to their function or decoration, but integrating ZooMS, they can also provide us with information of the choice of animal resources for bone artefacts which, as demonstrated, adds to our understanding of their production, use, and interpretation. ZooMS offers the opportunity to obtain a more complete picture of the use of animal resources by allowing us to include not only worked artefacts, but also the large material of unidentified animal bones without diagnostic traits. This not only applies to bone assemblages from medieval towns, but to animal bones across time periods, cultures, and geographical regions.

While other biomolecular methods might be used for species identification, ZooMS is cheaper and faster and more easily applicable than both regular aDNA analysis and shotgun DNA or proteomics methods. This has several advantages; for museums, this means that it is possible to perform large-scale ZooMS analysis of artefacts without over-burdening budgets. Also the species identification is within the guidelines of the Danish Museum Act. ${ }^{9}$ Combining traditional zooarchaeological analysis with ZooMS will enhance the outcome of both methods and give more complete data on past animal resources and how they were exploited. With the low costs it is moreover possible to do 'bulk analysis' that will go beyond identifying the species of different looking artefacts in the hope of detecting the presence of exotic and unexpected animals (e.g. 12,317 
samples, Buckley et al. 2017). Instead, it is possible to ask questions that require a larger body of analysed objects and enable construction of full biographies of the practices related to the use of animal resources and reveal patterns in trade and resource networks on a global, regional, and local scale. ZooMS can even be used as a screening tool and precursor to aDNA analysis. As an example ZooMS has been applied to Palaeolithic bone assemblages to reveal archaic hominins, which could then be subjected to further biomolecular analysis that can provide higher resolution data as aDNA and shotgun proteomics (Brown et al. 2016, Welker et al. 2016). This means that museums can select for destructive analysis (e.g. isotopes, DNA, radiocarbon dating) samples which have no morphological value instead of artefacts or elements with diagnostic characteristics (e.g. the right humerus of the Neandertal type specimen, Krings et al. 1997).

The reliability of ZooMS as a method for species identification has been independently confirmed in several studies (e.g. Von Holstein et al. 2014/1; Welker et al. 2015b, Evans et al. 2016). However there are two further considerations which should be born in mind before considering undertaking a study. Firstly the rate of collagen sequence evolution is relatively slow and consequently there may be instances, such as in the case of Indian/African elephants/mammoth, in which there are no differences within type I collagen (Buckley et al. 2011, Coutu et al. 2016). This may be particularly problematic if there is a large diversity of closely related species which could be utilised (e.g. Bovidae in Africa), but ZooMS is for instance diagnostic for most domesticated animals in Scandinavia. Secondly the quality of the identification is only as good as the quality of the database against which the samples are searched. Consequently there are cases in which samples could be misidentified, if the relevant species is not available. In these cases, the best match would be a closely related species, and if no unique masses are present, the identification may be mis-called.

The success rate of ZooMS is a function of the amount of collagen present in the sample which itself will decline in older bones, will be low in bones that have been cooked and absent in bones which have been burnt. For unburnt bone, Evans et al. (2016) report that 35/38 archaeological whale bones were identified to order, family or genus, and Ashby et al. report identifications to species for antler or animal bone for 469 of 705 combs or comb fragments from Danish Viking Age (Ashby et al. 2015). However, few studies report clear success rates, perhaps because samples can easily and without great cost be reprocessed. A second factor which may lead to poor results is if the extracts are highly discoloured for instance due to an abundance of humic acids from the soil. This can be a problem in urban deposits, but where this becomes a challenge is the case of tanned leather. It remains unclear as to why tanned leather has sometimes proven problematic for ZooMS (and also for DNA amplification, Vuissoz et al. 2007), it may be because the tanning agents interfere with the enzymes used in the assay or it may be that not all of the aromatic compounds are retained in the $\mathrm{C}_{18}$ clean up step and they may interfere with the laser ionisation step. For parchment (well preserved processed animal skins) which has never been buried, the eraser method even works better than destructive sampling (Fiddyment et al. 2015). However as demonstrated in the case-study from Odense, above, (for which 15 of 16 of the bone samples that had been sampled destructively worked compared to one of four of the ones sampled by eraser) that in order to have a high success rate it is necessary to take a sub-sample of the bone. Although the success rate for the eraser method on worked, bone, ivory and antler, is understandably lower, the lack of a sub-sample has obvious application, not least to portable art (e.g. Coutu et al. 2016).

Even where destructive sampling is used, the sample size can be so small that it is still possible to do the sampling in a area where the object can be photographed or put on display in a museum without showing the sample spot.

Although this article has focused on bone, bone assemblages are by no means the only suitable material for ZooMS. Collagen is also the major protein in skin, and the potential for ZooMS has been demonstrated on parchment as well as animal skin and connective tissues (Kirby et al. 2013, Fiddyment et al. 2015). This opens up for a enormous amount of skin-based materials of archaeological or historical origin including clothing, shoes, leather goods, furnishing, containers, wrappings, book bindings and skin-based glues. The fact that the database for keratin has been expanded (Solazzo et al. 2013, 2017, Solazzo 2017) opens up for an array of materials based on hair, feather, nail and baleen, not to mention textiles, for which the identification of fibre is an essential question. 
Leather, skin, and hair all face the same issues as bones in terms of species identification, which also for these is based on recognisable morphological traits and differences in the so-called grain pattern of skin, which varies between species, and characteristics of hair as hair diameter, the length of the fibres, and the appearance of the scales and medulla, which also varies between species. Once these morphological features are lost, all will rely upon molecular identification.

\section{Conclusion}

The analysis of the 20 samples from medieval Odense showed that there is a great and yet unexplored potential in analysing the artefacts that are made unidentifiable through manufacture. ZooMS will test assumptions on the choice of material for different purpose and enable interpretation that goes beyond the mere species identification. Through a precise and un-debatable species identification, we are able to ask questions regarding intended and unintended actions, identities, practices taking place in the town, etc. For Odense, long distance connections was demonstrated by the find of walrus tusk and the combs showed that the medieval comb maker would use the resources available to him in the town to create an affordable everyday object.

ZooMS is a fast, minimally or even non-destructive, easily applicable method for species identification, which has proven reliable and with a good success rate, and resolution for Scandinavian fauna. The potentials of ZooMS expand beyond animal bones and is for instance applied extensively for species identification of parchment (Fiddyment et al. 2015), but its potentials for skin and hair based materials are also great. In medieval Odense, the ongoing species identification of leather objects will enable a cross-correlation with the evidence obtained from the bone assemblage (O'Connor 2003, 3231-3235) and in Odense and in general the identifications of leather can enlighten aspects as skin trade and choices of leather for functional or signalling purposes.

At the moment ZooMS is a research method, but like many technologies before, as the approaches become standardised we are hoping that it is made available to a wider, non-specialised, audience. Like radiocarbon before it, it is hoped that in the future ZooMS will become a routine tool available to local museums conducting contract archaeology within Danish Museums Act part 8.

\section{Notes}

1. https://www.retsinformation.dk/Forms/R0710.aspx?id= 162504 (visited 21.09.2017).

2. http://slks.dk/fortidsminder-diger/arkaeologi-paa-land/ museernes-arkaeologiske-arbejde/vejledning-om-arkaeo logiske-undersoegelser/kap-6-konservering-og-naturvi denskab/\#c45926 (visited 21.09.2017).

3. Diplomatarium Danicum I, I nr. 343 s. 133-34. http:// dendigitalebyport.byhistorie.dk/medieval/item.aspx? itemid=391 (accessed 09-04-2018) .

4. http://museum.odense.dk/forskning/projekter/odensesopstaaen (accessed 21-09-2017).

5. A biological family of cloven-hoofed ruminant mammals including species such as bison, African buffalo, water buffalo, antelopes, sheep, goats, muskoxen, and domestic cattle.

6. A biological family of hoofed ruminant mammals including species such as elk, reindeer, fallow deer, and roe deer.

7. In theory also with horse, but this species can be eliminated by the peak 2131,1 (bovids/cervids) or 2145,1 (horse/zebra) which is often identified, but not shown in the displayed spectrum.

8. In Århus there was $2,7 \%$ horse bone in the 10th-12th century and $1,7 \%$ in the 13 th -14 th century. In Ribe there were 30 fragments of horse from the 8th-9th century.

9. https://slks.dk/fortidsminder-diger/arkaeologi-paa-land/ museernes-arkaeologiske-arbejde/vejledning-om-arkaeo logiske-undersoegelser/kap-6-konservering-og-naturvi denskab/.

\section{Acknowledgments}

We would like to thank Luke Spindler at BioArCh, University of York for his help with ZooMS sample preparation, MS, and inputs to the ZooMS protocol. We also thank Susanne Østergaard for her extensive work on the animal bones from Odense and Sidsel Frisch for help with preparing the figures.

\section{Funding}

This work was supported by the Carlsberg Foundation under Grant CF15-0573 (Fur and skin trade in Viking and medieval Denmark - A biomolecular investigation of archaeological fur, skin, and leather from Denmark and its contribution to the understanding of the Viking and medieval fur and skin trade), the Danish National Research Foundation under the Grant DNRF119 (Centre of Excellence for Urban Network Evolutions) and Grant DNRF128; and The Velux Foundation under Grant Urban Encounters (Urbaniseringens Møder og Mennesker). 


\section{ORCID}

Matthew J. Collins (D) http://orcid.org/0000-0003-4226-5501

\section{References}

Arneborg, J., 1999. Nordboliv i Grønland. Dagligliv $i$ Danmarks Middelalder. Available from: http://www.for skningsdatabasen.dk/en/catalog/2286836469.

Arneborg, J., 2000. Greenland and Europe. In William W. Fitzhugh and Elisabeth Ward (eds). Vikings. Washington, London: Smithsonian Institution Press. 304-318.

Ashby, S.P., 2009. Combs, contact and chronology: reconsidering hair combs in early-historic and viking-age atlantic Scotland, Medieval Archaeology, 53 (1), 1-33. Routledge. doi:10.1179/007660909X12457506806081

Ashby, S.P., 2014. A viking way of life. Stroud, Gloucestershire: Amberley Publishing Limited.

Ashby, S.P., Coutu, A.N., and Sindbæk, S.M., 2015. Urban networks and arctic outlands: craft specialists and reindeer antler in viking towns, European Journal of Archaeology, 18 (4), 679-704. Routledge. doi:10.1179/ 1461957115Y.0000000003

Badenhorst, S. and Plug, I., 2011. Unidentified specimens in zooarcheaology. Available from http://146.141.12.21/bit stream/handle/10539/13828/2011.v46.BADENHORST_ AND_PLUG_Unidentified_specimens_in_zooarchaeol ogy.pdf? sequence $=1$

Brandt, L.Ø., et al., 2014. Species identification of archaeological skin objects from danish bogs: comparison between mass spectrometry-based peptide sequencing and microscopy-based methods. PloS One, 9 (9), e106875. doi:10.1371/journal.pone.0106875

Brøgger, A.W., 1947. Kongespeilet. H. Oslo: Aschehoug.

Brown, S., et al. 2016. Identification of a new hominin bone from denisova cave, siberia using collagen fingerprinting and mitochondrial DNA analysis. Scientific Reports, 6 (March), 23559. doi:10.1038/srep23559

Buckley, M., et al., 2014. Species identification of archaeological marine mammals using collagen fingerprinting. Journal of Archaeological Science, 41 (January), 631-641. doi:10.1016/j.jas.2013.08.021

Buckley, M., Larkin, N., and Collins, M., 2011. Mammoth and mastodon collagen sequences; survival and utility, Geochimica Et Cosmochimica Acta, 75 (7), 2007-2016. Elsevier. doi:10.1016/j.gca.2011.01.022

Buckley, M., et al., 2009. Species identification by analysis of bone collagen using matrix-assisted laser desorption/ionisation time-of-flight mass spectrometry, Rapid Communications in Mass Spectrometry: RCM, 23 (23), 3843-3854. Wiley Online Library. doi:10.1002/rcm.4316

Buckley, M., Harvey, V.L., and Chamberlain, A.T., 2017. Species identification and decay assessment of late pleistocene fragmentary vertebrate remains from pin hole cave (Creswell Crags, UK) using collagen fingerprinting. Boreas, 46, 402-411. January. doi:10.1111/bor.12225

Cassidy, L.M., et al., 2017. Capturing goats: documenting two hundred years of mitochondrial DNA diversity among goat populations from Britain and Ireland. Biology Letters, 13 (3), 20160876. doi:10.1098/rsbl.2016.0876

Charlton, S., et al., 2016. Finding Britain's last hunter-gatherers: a new biomolecular approach to 'unidentifiable' bone fragments utilising bone collagen. Journal of Archaeological Science, 73 (September), 55-61. doi:10.1016/j.jas.2016.07.014

Christensen, A.S., 1988. Middelalderbyen Odense. Viby J: Centrum

Christophersen, A., 2015. Performing towns. Steps towards an understanding of medieval urban communities as social practice, Archaeological Dialogues, 22 (2), 109-132. Cambridge University Press. doi:10.1017/ S1380203815000161

Clutton-Brock, J., 1999. A natural history of domesticated mammals. Cambridge: Cambridge University Press.

Coutu, A.N., Whitelaw, G., and Le Roux, P. 2016. Earliest evidence for the ivory trade in Southern Africa. African Archaeological. Available from: http://eprints.whiterose.ac. uk/105511/1/Coutu_et_al_2016_African_Archaeological_ Review.pdf

Demarchi, B., et al. 2016. Protein sequences bound to mineral surfaces persist into deep time. eLife, 5 (September), e17092. doi:10.7554/eLife.17092

Enghoff, I.B., 2006. Pattedyr Og Fugle Fra Markedspladsen I Ribe, ASR 9 Posthuset. In: C. Feveile (ed.), Ribe Studier. Højbjerg: Jysk Arkæologisk Selskab, 167-187.

Evans, S., et al., 2016. Using combined biomolecular methods to explore whale exploitation and social aggregation in hunter-gatherer-fisher society in Tierra Del Fuego. Journal of Archaeological Science: Reports, 6 (Supplement C), 757-767. doi:10.1016/j.jasrep.2015.10.025

Fiddyment, S., et al. 2015. Animal origin of 13th-century uterine vellum revealed using noninvasive peptide fingerprinting. Proceedings of the National Academy of Sciences of the United States of America, 112 (49), 15066-15071. doi:10.1073/pnas.1512264112

Frandsen, L.B. 2006. "Ben Og Tak." In C. Feveile (ed): Ribe Studier. Det aldste Ribe. Udgravninger På Nordsiden Af Ribe A. Højbjerg: Jysk Arkæologisk Selskab, 1984-2000. Bind 1.2.

Hillson, S., 1992. Mammal bones and teeth, institute of archaeology. London: Taylor \& Francis Ltd.

Hollemeyer, K., Altmeyer, W., and Heinzle, E. 2007. "Identification of furs of domestic dog, raccoon dog, rabbit and domestic cat by hair analysis using MALDI-ToF mass spectrometry." Spectroscopy Europe. Available from https://www.researchgate.net/profile/Klaus_Hollemeyer/ publication/258436423_Identification_of_Furs_of_ Domestic_Dog_Raccoon_Dog_Rabbit_and_Domestic_ Cat_by_Hair_Analysis_using_MALDI-TOF_Mass_spectro metry/links/004635283793478824000000.pdf 
Hollemeyer, K., Altmeyer, W., and Heinzle, E., 2008. Species identification of oetzi's clothing with matrix-assisted laser desorption/ionization time-of-flight mass spectrometry based on peptide pattern similarities of hair. Rapid Communication in Mass spectrometry. Wiley Online Library, 22(18):2751-67. Retrieved from. http://onlineli brary.wiley.com/doi/10.1002/rcm.3679/full.

Hollemeyer, K., Altmeyer, W., and Heinzle, E., 2002. Identification and quantification of feathers, down, and hair of avian and mammalian origin using matrix-assisted laser desorption/ionization time-of-flight mass spectrometry. Analytical Chemistry, 74 (23), 5960-5968. doi:10.1021/ ac020347f

Hollemeyer, K., et al., 2012. Matrix-assisted laser desorption/ ionization time-of-flight mass spectrometry combined with multidimensional scaling, binary hierarchical cluster tree and selected diagnostic masses improves species identification of neolithic keratin sequences from furs of the tyrolean iceman Oetzi. Rapid Communications in Mass Spectrometry: RCM, 26 (16), 1735-1745.

Hybel, N. and Poulsen, B., 2007. The Danish resources $C$. 1000-1550: growth and Recession. Leiden, Boston: Brill.

Jensen, P. M. and Østergaard, S. 2017. Handel med nord og syd. In: M. Runge and J. Hansen eds. Knuds Odense - vikingernes by. Odense Bys Museer. Odense, 177179.

Kirby, D.P., et al., 2013. Identification of collagen-based materials in cultural heritage. The Analyst, 138 (17), 4849-4858. doi:10.1039/c3an00925d

Kistler, L., et al., 2017. A new model for ancient DNA decay based on paleogenomic meta-analysis. Nucleic Acids Research, 45 (11), 6310-6320. Cold Spring Harbor Labs Journals. doi:10.1093/nar/gkx361

Krings, M., et al., 1997. Neandertal DNA sequences and the origin of modern humans, Cell, 90 (1), 19-30. Elsevier. doi:10.1016/S0092-8674(00)80310-4

Larsen, J.L., 2005. Kammageren. Takmaterialet Fra Viborg Søndersø. In: M. Iversen, et al., eds. Viborg Søndersø 1018-1030. Arkoologi Og Naturvidenskab I et Vorkstedsområde Fra Vikingetid. Højbjerg: Jysk Arkæologisk Selskab.

Lee Lyman, R., 1994. Vertebrate taphonomy. Cambridge: Cambridge University Press.

Librado, P., et al. 2017. Ancient genomic changes associated with domestication of the horse. Science, 356 (6336), 442445. doi:10.1126/science.aam5298

Liebgott, N.-K., 1985. Elfenben. København: Nationalmuseet. Linaa, J. 2015. "Crafts in the landscape of the powerless. A combmaker's workshop at Viborg Søndersø AD 1020-1024." In G. Hansen, S. Ashby, I. Baug (eds.). Everyday Products in the Middle Ages: Crafts, Consumption and the Individual in Northern Europe c. AD 800-1600. Oxbow Books, Oxford, 69-90.

Møhl, U., 1971. Et Knoglemateriale Fra Vikingetid Og Middelalder I Århus. Århus Søndervold. En Byarkoologisk Undersøgelse, In H. H. Andersen, P. J. Crabb, H. J. Madsen, (eds.). København: Gyldendal. 321-329.
O'Sullivan, N.J., et al., 2016. A whole mitochondria analysis of the tyrolean iceman's leather provides insights into the animal sources of copper age clothing, Scientific Reports, 6 (August), 31279. nature.com. doi:10.1038/srep31279

Orton, D.C., 2012. Taphonomy and interpretation: an analytical framework for social zooarchaeology, International Journal of Osteoarchaeology, 22 (3), 320-337. John Wiley \& Sons, Ltd. doi:10.1002/oa.v22.3

Østergaard, S., 2016. Dyreknoglerne Fra Odense Midtby. OBM 9776, Vilhelm Werners Plads (FHM 96/1392. Rapport over Det Samlede Dyreknoglemateriale. Moesgaard Museum 2016. Unpublished report.

Øye, I. 2005. “Kammer, Kjønn Og Kontekst.” UBAS Nordisk 1. Fra Funn Til Samfunn. Jernalderstudier. Available from http://bora.uib.no/bitstream/handle/1956/11376/kammerkjonn-og-kontekst.pdf? sequence $=1$

Presslee, S., et al. 2018. The identification of archaeological eggshell using peptide markers. STAR: Science \& Technology of Archaeological Research, 4 (1), 13-23. Routledge

Richter, K.K., et al., 2011. Fish'n chips: zooMS peptide mass fingerprinting in a 96 well plate format to identify fish bone fragments, Journal of Archaeological Science, 38 (7), 1502-1510. Elsevier. doi:10.1016/j.jas.2011.02.014

Roesdahl, E., 1999. Dagligliv i Danmarks middelalder: en arkoeologisk kulturhistorie. København: Gyldendal.

Schmidt, A.L., et al. 2013. "Identification of animal species in skin clothing from museum collections." In ICOM-CC 16 Th Triennial Conference. http://www.forskningsdatabasen. $\mathrm{dk} / \mathrm{en} /$ catalog/2265160182.

Shoulders, M.D. and Raines, R.T., 2009. Collagen structure and stability. Annual Review of Biochemistry, 78, 929-958. doi:10.1146/annurev.biochem.77.032207.120833

Smith, C.I., et al., 2003. The thermal history of human fossils and the likelihood of successful DNA amplification, Journal of Human Evolution, 45 (3), 203-217. Elsevier. doi:10.1016/S0047-2484(03)00106-4

Solazzo, C. 2017. "Follow-up on the characterization of peptidic markers in hair and fur for the identification of common North American species." Rapid Communications in Mass Spectrometry: RCM. Wiley Online Library. http://onlineli brary.wiley.com/doi/10.1002/rcm.7923/full.

Solazzo, C., et al., 2017. Molecular markers in keratins from mysticeti whales for species identification of baleen in museum and archaeological collections. PloS One, 12 (8), e0183053. doi:10.1371/journal.pone.0183053

Solazzo, C., et al., 2013. Characterisation of novel a-keratin peptide markers for species identification in keratinous tissues using mass spectrometry, Rapid Communications in Mass Spectrometry: RCM, 27 (23), 2685-2698. Wiley Online Library. doi:10.1002/rcm.6730

Solazzo, C., et al., 2014. Species identification by peptide mass fingerprinting (PMF) in fibre products preserved by association with copper-alloy artefacts. Journal of Archaeological Science, 49 (September), 524-535. doi:10.1016/j.jas.2014.06.009

Steele, T.E., 2015. The contributions of animal bones from archaeological sites: the past and future of zooarchaeology. 
Journal of Archaeological Science, 56 (April), 168-176. doi:10.1016/j.jas.2015.02.036

Stewart, J.R.M., et al., 2013. ZooMS: making eggshell visible in the archaeological record. Journal of Archaeological Science, 40 (4), 1797-1804. doi:10.1016/j.jas.2012.11.007

Strohalm, M., et al., 2008. mMass data miner: an open source alternative for mass spectrometric data analysis, Rapid Communications in Mass Spectrometry: RCM, 22 (6), 905-908. Wiley Online Library. doi:10.1002/rcm.3444

O'Connor, T., 2000. The archaeology of animal bones. Stroud: Sutton Publishing Limited.

O'Connor, T., 2003. The Osteological Evidence. In: Q. Mould, I. Carlisle, and E.A. Cameron, eds. Craft, industry and everyday life: leather and leatherworking in anglo-scandinavian and medieval York. London: Council for British Archaeology.

van Doorn, N.L., Hollund, H., and Collins, M.J., 2011. A novel and non-destructive approach for ZooMS analysis: ammonium bicarbonate buffer extraction, Archaeological and Anthropological Sciences, 3 (3), 281. Springer-Verlag. doi:10.1007/s12520-011-0067-y

Von Holstein, I.C.C., et al., 2014. Searching for scandinavians in pre-viking Scotland: molecular fingerprinting of early medieval combs, Journal of Archaeological Science, 41, 1-6. Academic Press. doi:10.1016/j.jas.2013.07.026
Vuissoz, A., et al., 2007. The survival of PCR-amplifiable DNA in cow leather, Journal of Archaeological Science, 34 (5), 823-829. Elsevier. doi:10.1016/j.jas.2006.09.002

Welker, F. 2017. The Palaeoproteomic Identification of Pleistocene Hominin Skeletal Remains: Towards a Biological Understanding of the Middle to Upper Palaeolithic Transition. PhD Dissertation. Max-PlanckInstitute for Evolutionary Anthropology.

Welker, F., et al. 2015a. Ancient proteins resolve the evolutionary history of Darwin's South American Ungulates. Nature, 522 (7554), 81-84. doi:10.1038/nature14249

Welker, F., et al. 2016. Palaeoproteomic evidence identifies archaic hominins associated with the Châtelperronian at the Grotte Du Renne. Proceedings of the National Academy of Sciences of the United States of America, 113 (40), 11162-11167. doi:10.1073/pnas.1605834113

Welker, F., et al., 2015b. Using ZooMS to identify fragmentary bone from the late middle/early upper palaeolithic sequence of Les Cottés, France. Journal of Archaeological Science, 54 (Supplement C), 279-286. doi:10.1016/j. jas.2014.12.010

Westbury, M., et al. 2017. A mitogenomic timetree for Darwin's Enigmatic South American mammal macrauchenia patachonica. Nature Communications, 8 (June), 15951. doi:10.1038/ncomms15951 